\title{
Pseudomonas azotifigens sp. nov., a novel nitrogen-fixing bacterium isolated from a compost pile
}

\author{
Kouta Hatayama, ${ }^{1}$ Satomi Kawai, ${ }^{1}$ Hirofumi Shoun, ${ }^{2}$ Yasuichi Ueda ${ }^{3}$ \\ and Akira Nakamura ${ }^{1}$
}

Correspondence

Akira Nakamura

a-nak@agbi.tsukuba.ac.jp

\author{
${ }^{1}$ Division of Integrative Environmental Sciences, Graduate School of Life and Environmental \\ Sciences, University of Tsukuba, Tennodai 1-1-1, Tsukuba, Ibaraki 305-8572, Japan \\ ${ }^{2}$ Department of Biotechnology, Graduate School of Agricultural and Life Sciences, \\ The University of Tokyo, Yayoi 1-1-1, Bunkyo-ku, Tokyo 113-8657, Japan \\ ${ }^{3}$ Institute of Hyperthermophiles, Motobu-Noge Hospital, Aza-Ohama 880-1, Motobu, Okinawa \\ 905-0212, Japan
}

\begin{abstract}
A nitrogen-fixing bacterium, designated strain $6 \mathrm{H}_{3} 3 \mathrm{~b}^{\top}$, was isolated from a compost pile in Japan. The nitrogenase activity of this strain was detected based on its acetylene-reducing activity under low oxygen concentrations (2-4\%). An analysis of the genes responsible for nitrogen fixation in this strain, nifH and nifD, indicated a close relationship to those of Pseudomonas stutzeri A15 (A1501). Sequence similarity searches based on the 16S rRNA gene sequences showed that strain $6 \mathrm{H}_{3} 3 \mathrm{~b}^{\top}$ belongs within the genus Pseudomonas sensu stricto; closest similarity was with Pseudomonas indica (97.3\%). A comparison of several taxonomic characteristics of $6 \mathrm{H}_{3} 3 \mathrm{~b}^{\top}$ with those of $P$. indica and some type strains of the genus Pseudomonas sensu stricto indicated that $6 \mathrm{H} 33 \mathrm{~b}^{\top}$ could be distinguished from $P$. indica based on the presence of nitrogen fixation ability, the absence of nitrate reduction and denitrification abilities and the utilization of some sugars and organic acids. Phylogenetic analyses and the results of DNA-DNA hybridization experiments also indicated that strain $6 \mathrm{H}_{3} 3 \mathrm{~b}^{\top}$ represents a species distinct from $P$. indica. From these results, it is proposed that strain $6{\mathrm{H} 33 \mathrm{~b}^{\top}}^{\top}\left(=\mathrm{ATCC} \mathrm{BAA}-1049^{\top}=\mathrm{JCM} 12708^{\top}\right)$ is classified as the type strain of a novel species of the genus Pseudomonas sensu stricto under the name Pseudomonas azotifigens sp. nov.
\end{abstract}

The genus Pseudomonas sensu stricto includes species with various characteristics, such as the ability to degrade aromatic compounds and xenobiotics, and which are pathogenic to plants and animals. However, nitrogen fixation ability within the genus is poorly understood. It was believed that no strains in this genus were legitimate nitrogenfixers (Young, 1992), but recent studies have demonstrated that several strains, classified as Pseudomonas stutzeri, do have the ability to fix nitrogen (Krotzky \& Werner, 1987; Vermeiren et al., 1999; Desnoues et al., 2003). Among them, P. stutzeri A15 (A1501), isolated from rice paddies in China,

Published online ahead of print on 17 February 2005 as DOI 10.1099/ ijs.0.63586-0.

The GenBank/EMBL/DDBJ accession numbers for the 16S rRNA and nifHD gene sequences of strain $6 \mathrm{H}_{3} 3 \mathrm{~b}^{\top}$ are respectively $\mathrm{AB} 189452$ and AB189453.

A phylogenetic tree based on the nifH gene sequence of $6 \mathrm{H} 33 \mathrm{~b}^{\top}$ and other representative members of the $\beta$ - and $\gamma$-Proteobacteria is available as a supplementary figure in IJSEM Online. was studied in detail to determine the conditions under which nitrogen fixation occurred and the structure of the nitrogenase genes involved (Desnoues et al., 2003).

A unique composting process has recently been developed, referred to as 'hyperthermal composting', which consists of rapid composting at high temperatures using a newly developed hyperthermal composting machine. When the final compost pile produced by this process was packed in polyethylene bags and sealed, several bags were found to be almost completely deflated after about 2 weeks at room temperature, similar to 'vacuum-packing'. Repacking of this compost produced the same result, i.e. a loss of atmospheric gas pressure after 2 weeks. It was considered that this result might have been achieved through biological nitrogen fixation, because nitrogen gas $(80 \%$ of the atmosphere) must have been lost. Screening of the nitrogen-fixing micro-organism(s) from the 'vacuum-packed' compost was therefore undertaken. We report the isolation of a novel nitrogen-fixing species of the genus Pseudomonas sensu stricto from this sample. 
Five grams of a sample from the 'vacuum-packed' compost was inoculated in $100 \mathrm{ml} \mathrm{N}$-free minimum medium (NFMM; 0.18 g K $\mathrm{HPO}_{4}, 0.026 \mathrm{~g} \mathrm{KH}_{2} \mathrm{PO}_{4}, 0.16 \mathrm{~g} \mathrm{NaCl}$, $0.24 \mathrm{~g} \mathrm{MgSO}_{4} .7 \mathrm{H}_{2} \mathrm{O}, 2 \mathrm{mg} \mathrm{CaCl}, 2 \mathrm{mg} \mathrm{FeCl}_{3}, 0 \cdot 2 \mathrm{mg}$ $\mathrm{ZnSO}_{4} .7 \mathrm{H}_{2} \mathrm{O}, 0.06 \mathrm{mg} \mathrm{MnCl}_{2} .4 \mathrm{H}_{2} \mathrm{O}, 0.6 \mathrm{mg} \mathrm{H}_{3} \mathrm{BO}_{3}$, $0.4 \mathrm{mg} \mathrm{CoCl}_{2} .6 \mathrm{H}_{2} \mathrm{O}, 0.02 \mathrm{mg} \mathrm{CuCl}_{2} .2 \mathrm{H}_{2} \mathrm{O}, 0.04 \mathrm{mg}$ $\mathrm{NiCl}_{2} \cdot 6 \mathrm{H}_{2} \mathrm{O}, 10 \mathrm{mg} \mathrm{Na} \mathrm{MoO}_{4} \cdot 2 \mathrm{H}_{2} \mathrm{O}, 5 \cdot 0 \mathrm{ml}$ acetic acid, $1000 \mathrm{ml}$ distilled water, $\mathrm{pH} 7 \cdot 0$ ) and cultured for 2 weeks at $30^{\circ} \mathrm{C}$. A portion of this culture was transferred to fresh NFMM and cultivated again for 2 weeks. This treatment was repeated, and the final culture was then spread onto NFMMagar plates to obtain single colonies. Many types of colonies were initially observed, but most did not grow when they were cultured again in liquid NFMM (data not shown). Only one colony, designated strain $6 \mathrm{H} 33 \mathrm{~b}^{\mathrm{T}}$, grew when re-cultured. This strain was then further investigated. Strain $6 \mathrm{H} 33 \mathrm{~b}^{\mathrm{T}}$ grew in an aggregated form in NFMM and required several weeks to reach the stationary phase of growth. As $6 \mathrm{H} 33 \mathrm{~b}^{\mathrm{T}}$ also grew on Luria-Bertani (LB) medium, this medium was used to maintain the strain for further work. Cells of strain $6 \mathrm{H}_{3} 3 \mathrm{~b}^{\mathrm{T}}$ formed translucent, wrinkled, obscure-edged colonies on an LB agar plate. Microscopic observation revealed that cells were Gram-negative, straight rods, $2-5 \mu \mathrm{m}$ long and $0.5 \mu \mathrm{m}$ wide, and motile.

An acetylene reduction assay, a modification of the method of Desnoues et al. (2003), was used to detect the nitrogenase activity of $6 \mathrm{H} 33 \mathrm{~b}^{\mathrm{T}}$. Cells cultured in LB medium overnight were washed with NFMM three times and suspended in NFMM to give an $\mathrm{OD}_{600}$ of $0 \cdot 08$. Five millilitres of this suspension was transferred to $20 \mathrm{ml}$ tubes and sealed with rubber caps. After the tubes were degassed once, the headspace gas of the tubes was replaced by argon gas, and acetylene and oxygen gasses were added to final concentrations of $10 \%(\mathrm{v} / \mathrm{v})$ and a range from 0 to $6 \%(\mathrm{v} / \mathrm{v})$, respectively. The tubes were incubated at $30^{\circ} \mathrm{C}$ with shaking, and $0.5 \mathrm{ml}$ of the headspace gas was taken periodically for measurement of ethylene formation. Detection of ethylene was performed using GC with an HP 6890 series (Hewlett Packard) gas chromatograph equipped with a thermal conductivity detector. Injector and detector temperatures were set to $80^{\circ} \mathrm{C}$. The column used was a Porapak N $(80 / 100$ mesh, diameter $2.3 \mathrm{~mm} \times 2.0 \mathrm{~m}$; GL-Sciences), and the carrier gas was $\mathrm{N}_{2}$ delivered at a flow rate of $30 \mathrm{ml} \mathrm{min}{ }^{-1}$. This assay was performed three times. Strain $6 \mathrm{H} 33 \mathrm{~b}^{\mathrm{T}}$ was observed to reduce acetylene to ethylene at an oxygen concentration of $2-6 \%$ (Fig. 1). The highest nitrogenase activity was detected at $4 \%$ oxygen, with no activity at $0 \%$. This result indicated that the nitrogenase activity of $6 \mathrm{H} 33 \mathrm{~b}^{\mathrm{T}}$ was controlled against oxygen tension, as reported for P. stutzeri A15 (A1501) (Desnoues et al., 2003) and for some diazotrophs (Bergersen, 1991).

The nifH gene sequence of $6 \mathrm{H} 33 \mathrm{~b}^{\mathrm{T}}$, which encodes nitrogenase reductase, was analysed as follows. PCR amplification of a partial nifH fragment was performed using the method of Bürgmann et al. (2004) by using the total DNA of strain $6 \mathrm{H} 33 \mathrm{~b}^{\mathrm{T}}$, which was extracted using the method of

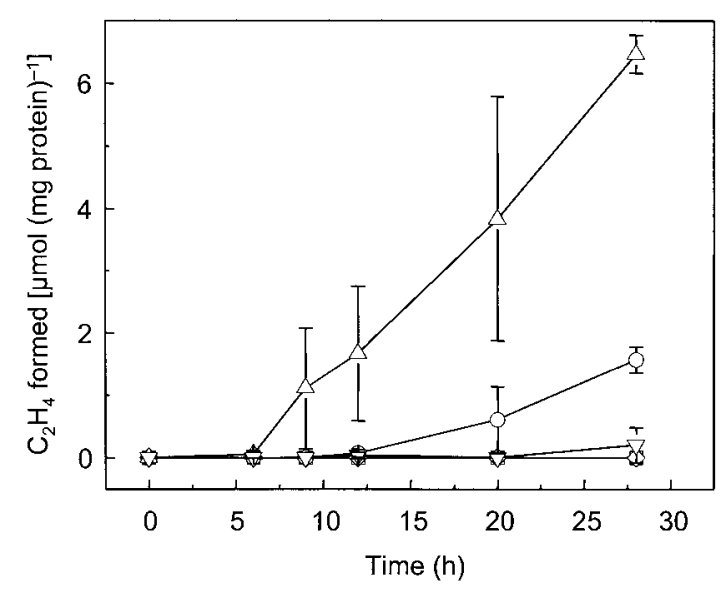

Fig. 1. Effect of oxygen concentration in the gas phase on the nitrogenase activity of strain $6 \mathrm{H}_{3} 3 \mathrm{~b}^{\top}$. Oxygen concentrations were $0(\square), 1 \%(\diamond), 2 \%(\bigcirc), 4 \%(\triangle)$ and $6 \%(\nabla)(\mathrm{v} / \mathrm{v})$.

Perego et al. (1988). The product (331 bp) was cloned with the pGEM-T vector system (Promega). To obtain the fulllength nifH gene sequence, a Southern blot analysis and subsequent colony hybridization were performed with the cloned PCR fragment as a probe using a DIG DNA labelling kit (Roche Diagnostics) and a DIG nucleic acid detection kit (Roche Diagnostics). In the Southern blot analysis, total DNA of strain $6 \mathrm{H} 33 \mathrm{~b}^{\mathrm{T}}$ was digested with EcoRI, HindIII or PstI and blotted on a Hybond- ${ }^{+}$membrane (Amersham Biosciences). Hybridization signals were observed at about $9 \cdot 0 \mathrm{~kb}$, at more than $10 \mathrm{~kb}$ and at $3 \cdot 2 \mathrm{~kb}$, respectively, with these fragments (data not shown). The $3 \cdot 2 \mathrm{~kb}$ PstI fragment was selected and cloned into pUC118 by colony hybridization, using a Hybond-C membrane (Amersham Biosciences). Sequencing of the cloned fragment was performed with a CEQ DTCS-quick start kit (Beckman Coulter) and a CEQ 2000 XL sequencing system (Beckman Coulter) using the M13 forward and reverse primers and primers generated from the internal sequence of the fragment. The sequence of the PstI fragment was $3196 \mathrm{bp}$ in length (GenBank accession no. AB189453) and contained the complete nifH gene sequence ( $882 \mathrm{bp}$ ) and a partial nifD gene sequence $(1428 \mathrm{bp})$. Similarity searches in BLASTN (Altschul et al., 1997) and FASTA (Pearson, 2000) indicated that the nifH and nifD gene sequences of $6 \mathrm{H} 33 \mathrm{~b}^{\mathrm{T}}$ showed the highest similarity to those of the nifH (GenBank accession no. X96609) and nifD (GenBank accession no. X95565) genes of P. stutzeri A15 (A1501) (96.6 and $93 \cdot 2 \%$ similarity, respectively). Moderate similarities were found to the nifH and nifD gene sequences of strains of other representative $\beta$ - and $\gamma$-proteobacteria (see Supplementary Fig. S1 in IJSEM Online).

To determine the phylogenetic position of strain $6 \mathrm{H} 33 \mathrm{~b}^{\mathrm{T}}$, its $16 \mathrm{~S}$ rRNA gene sequence was analysed. PCR amplification of a 16S rRNA gene fragment was conducted with primers Eubac27F and 1492R (DeLong, 1992) using Ex Taq (Takara 
Shuzo) and a PCR System 9700 (PE Applied Biosystems). After agarose-gel electrophoresis, the fragment was purified using an EZNA gel extraction kit (Omega). Sequencing was performed with the same system described above for the nifH $H$ and nifD gene sequences using the primers reported by Hiraishi (1992) and Hiraishi et al. (1994). The 16S rRNA gene sequence of strain $6 \mathrm{H} 33 \mathrm{~b}^{\mathrm{T}}$ was aligned at positions 32-1489 (Escherichia coli numbering system; Brosius et al., 1978) with those of representative strains of the genus Pseudomonas sensu stricto using the CLUSTAL X software package (Thompson et al., 1997). Distance values were calculated using the method described by Kimura (1980), which were then used in CLUSTAL X to construct a phylogenetic tree via the neighbour-joining method (Saitou \& Nei, 1987) with bootstrap values (Felsenstein, 1985) based on 1000 replications. A maximum-likelihood analysis was performed in DNAML with bootstrap values based on 100 replications using the SEQBOOT and CONSENSE programs of the PHYLIP package, version 3.6a3 (Felsenstein, 2002). Visualization of these results was provided by TreeView software (Page, 1996). The 16S rRNA gene sequence of $6 \mathrm{H} 33 \mathrm{~b}^{\mathrm{T}}$ (1458 bp) showed closest similarity to that of Pseudomonas indica $\mathrm{IMT}^{\mathrm{T}} \mathrm{T}^{\mathrm{T}}(97 \cdot 3 \%$ similarity), and a relationship to strains of the genus Pseudomonas sensu stricto was tested. Phylogenetic analyses based on the $16 \mathrm{~S}$ rRNA gene sequences, performed using the neighbourjoining (Fig. 2) and maximum-likelihood (data not shown) methods, indicated that strain $6 \mathrm{H} 33 \mathrm{~b}^{\mathrm{T}}$ belongs to the genus Pseudomonas sensu stricto. Although differences in branching were found between the two trees, that between $6 \mathrm{H} 33 \mathrm{~b}^{\mathrm{T}}$ and $P$. indica IMT37 $37^{\mathrm{T}}$ was supported with high bootstrap values (above $96 \%$ ) in both. These observations suggest that $6 \mathrm{H} 33 \mathrm{~b}^{\mathrm{T}}$ and $P$. indica IMT $37^{\mathrm{T}}$ are representative of different species.

To characterize $6 \mathrm{H}_{3} 3 \mathrm{~b}^{\mathrm{T}}$ in more detail, comparisons of several physiological characteristics were performed among $6 \mathrm{H}_{3} 3 \mathrm{~b}^{\mathrm{T}}, P$. indica DSM $14015^{\mathrm{T}}\left(=\mathrm{IMT} 37^{\mathrm{T}}\right)$ as its closest related strain, and Pseudomonas aeruginosa NCIMB $8295^{\mathrm{T}}$ and P. stutzeri NCIMB $11358^{\mathrm{T}}$ as typical strains of the genus
Pseudomonas sensu stricto. Production of pyocyanin and fluorescent pigments were tested via growth in medium A of King et al. (1954) and the medium described by Luisetti et al. (1972). Nitrate reduction and denitrification were tested according to the methods of Lelliott et al. (1966) and Stanier et al. (1966), respectively. Nitrogen fixation was tested using the method described by us above. Utilization of various carbon sources was determined in triplicate using a Biolog GN2 MicroPlate, as recommended by the manufacturer. The $\mathrm{G}+\mathrm{C}$ content of the DNA of strain $6 \mathrm{H} 33 \mathrm{~b}^{\mathrm{T}}$ and the reference strains was determined by the method of Tamaoka \& Komagata (1984). Other physiological characteristics were tested as described by Palleroni (1984). Strain $6 \mathrm{H} 33 \mathrm{~b}^{\mathrm{T}}$ grew over a $\mathrm{pH}$ range of $6 \cdot 1-9 \cdot 8$ and at $28-41{ }^{\circ} \mathrm{C}$ in $\mathrm{LB}$ medium. It reacted positively in oxidase and catalase tests and in a test for hydrolysis of Tween 80, as did the three reference strains. Other physiological characteristics of strain $6 \mathrm{H} 33 \mathrm{~b}^{\mathrm{T}}$ differed from those of the reference strains, such as the production of pigments, nitrate reduction, denitrification, resistance to $\mathrm{NaCl}$ and the utilization of some substrates (Table 1). Of the four strains tested, only $6 \mathrm{H} 33 \mathrm{~b}^{\mathrm{T}}$ was able to fix nitrogen. Although nitrogen fixation was reported in P. stutzeri A15 (A1501), the type strain of $P$. stutzeri indicated a negative reaction. The $\mathrm{G}+\mathrm{C}$ content of the DNA of $6 \mathrm{H}_{3} 3 \mathrm{~b}^{\mathrm{T}}$ was $66 \cdot 3 \mathrm{~mol} \%$, which was in good agreement with the values of the genus Pseudomonas sensu stricto (58-70 mol\%; Palleroni, 1984).

Phylogenetic analysis based on the 16S rRNA gene sequence of strain $6 \mathrm{H} 33 \mathrm{~b}^{\mathrm{T}}$ indicated that it is a member of the genus Pseudomonas sensu stricto. Differences in some of the physiological and biochemical characteristics and the phylogenetic position based on 16S rRNA gene sequence analysis between $6 \mathrm{H} 33 \mathrm{~b}^{\mathrm{T}}$ and other members of the genus suggested that $6 \mathrm{H} 33 \mathrm{~b}^{\mathrm{T}}$ represents a novel species. This was further suggested based on the low level of DNA-DNA hybridization, as determined using the method of Ezaki et al. (1989), between $6 \mathrm{H} 33 \mathrm{~b}^{\mathrm{T}}$ and its closest relative, $P$. indica DSM $14015^{\mathrm{T}}$ (1-5\% similarity; data not shown). Strain $6 \mathrm{H} 33 \mathrm{~b}^{\mathrm{T}}$ therefore represents a novel species of the genus

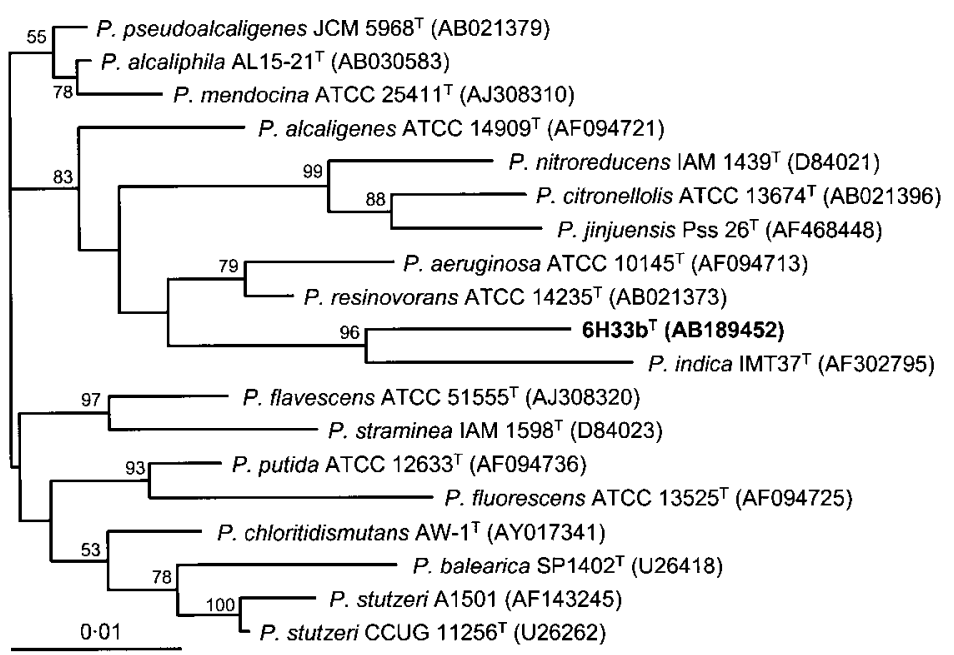

Fig. 2. Phylogenetic tree based on the $16 \mathrm{~S}$ rRNA gene sequences of strain $6 \mathrm{H}_{3} 3 \mathrm{~b}^{\top}$, type strains of the genus Pseudomonas sensu stricto and $P$. stutzeri A1501. The tree was drawn by the neighbour-joining method. Bootstrap percentages were calculated from 1000 repeats and those greater than $50 \%$ are shown at branch points. Numbers in parentheses are the GenBank accession numbers. Bar, 0.01 substitutions per nucleotide position. 
Table 1. Comparison of physiological and biochemical characteristics between strain $6 \mathrm{H}_{3} 3 \mathrm{~b}^{\top}$ and three type strains of the genus Pseudomonas sensu stricto

Strains: $1,6 \mathrm{H}_{3} \mathrm{~b}^{\mathrm{T}} ; 2$, P. aeruginosa NCIMB $8295^{\mathrm{T}}$; 3, P. indica DSM $14015^{\mathrm{T}} ; 4$, P. stutzeri NCIMB $11358^{\mathrm{T}}$

\begin{tabular}{|c|c|c|c|c|}
\hline Characteristic & 1 & 2 & 3 & 4 \\
\hline \multicolumn{5}{|l|}{ Production of: } \\
\hline Pyocyanin & - & + & - & - \\
\hline Fluorescent pigments & - & + & - & - \\
\hline Nitrate reduction & - & + & $+^{*}$ & + \\
\hline Denitrification & - & + & + & + \\
\hline Nitrogen fixation & + & - & - & - \\
\hline \multicolumn{5}{|c|}{ Growth in the presence of $\mathrm{NaCl}$ at: $\dagger$} \\
\hline $5 \%$ & + & + & $+^{*}$ & + \\
\hline $7 \%$ & - & - & - & + \\
\hline Hydrolysis of starch & + & - & + & + \\
\hline \multicolumn{5}{|l|}{ Utilization of: $\ddagger$} \\
\hline$N$-Acetyl-D-glucosamine & - & + & - & - \\
\hline L-Arabinose & - & - & + & - \\
\hline 2,3-Butanediol & - & + & + & - \\
\hline DL-Carnitine & - & + & + & - \\
\hline Dextrin & - & + & + & + \\
\hline D-Galacturonic acid & - & - & + & - \\
\hline D-Glucuronic acid & - & - & + & - \\
\hline Glycerol & - & + & + & + \\
\hline L-Histidine & - & + & + & - \\
\hline Hydroxy-L-proline & + & + & - & - \\
\hline Inosine & - & + & - & - \\
\hline Malonic acid & - & + & + & + \\
\hline Quinic acid & - & + & + & - \\
\hline D-Saccharic acid & + & - & + & - \\
\hline Urocanic acid & - & + & + & - \\
\hline DNA G $+\mathrm{C}$ content $(\mathrm{mol} \%)$ & $66 \cdot 3 \pm 0 \cdot 5$ & $65 \cdot 2 \pm 0 \cdot 5$ & $63 \cdot 5 \pm 0 \cdot 7$ & $63 \cdot 2 \pm 0 \cdot 3$ \\
\hline
\end{tabular}

*A negative reaction was reported by Pandey et al. (2002).

$\dagger$ All the strains grew in $2.5 \% \mathrm{NaCl}$ and did not grow in $10 \% \mathrm{NaCl}$.

‡Only substrates for which a difference was observed among the four strains are listed.

Pseudomonas sensu stricto, for which the name Pseudomonas azotifigens is proposed.

From the phylogenetic tree constructed based on the nifH gene sequences, the nifH genes of $P$. azotifigens $6 \mathrm{H} 33 \mathrm{~b}^{\mathrm{T}}$ and P. stutzeri A15 (A1501) appear to have evolved from a common ancestral gene (Supplementary Fig. S1). However, the nitrogenase genes were not found in other Pseudomonas species, and Southern blot analysis with the nifH fragment of strain $6 \mathrm{H} 33 \mathrm{~b}^{\mathrm{T}}$ as a probe revealed the absence of nifH-like genes in the genomes of its most closely related type strains, P. indica DSM $14015^{\mathrm{T}}$ and P. stutzeri NCIMB $11358^{\mathrm{T}}$ (data not shown). This was in good agreement with the results of the nitrogenase assay. These results strongly indicated that nitrogen fixation ability in Pseudomonas sensu stricto is a strain-specific characteristic, and that there may have been a complex evolutionary history of the nitrogenase genes in the genus. One possible explanation is that the nitrogenase genes may have been lost from the other Pseudomonas strains, especially the type strain of $P$. stutzeri, after the strains NCIMB $11358^{\mathrm{T}}$ and A15 (A1501) diverged. Alternatively, the nitrogenase genes of $P$. azotifigens $6 \mathrm{H} 33 \mathrm{~b}^{\mathrm{T}}$ and P. stutzeri A15 (A1501) may have been horizontally transferred from other diazotroph(s) after these strains were established. Isolation and characterization of novel nitrogen-fixers in the genus Pseudomonas sensu stricto, together with analysis of nitrogen fixation within recognized Pseudomonas species, may provide further data on the evolutionary history of the nitrogenase genes in this genus.

\section{Description of Pseudomonas azotifigens sp. nov.}

Pseudomonas azotifigens [a.zo.ti.fi'gens. French n. azote (from Gr. pref. $a$ - and Gr. n. zoê) nitrogen; N.L. n. azotum - $i$ 
nitrogen; L. part. figens (from L. v. figo) fixing; N.L. part. adj. azotifigens nitrogen fixing].

Cells are Gram-negative straight rods, $2-5 \mu \mathrm{m}$ long and $0.5 \mu \mathrm{m}$ wide, and motile. Colonies are translucent, wrinkled and with obscure edges when grown on LB agar. Growth in $\mathrm{LB}$ medium is observed at $\mathrm{pH} 6 \cdot 1-9 \cdot 8,28-41{ }^{\circ} \mathrm{C}$ and in the presence of $2 \cdot 5-5 \% \mathrm{NaCl}$. Nitrogen fixation in NFMM is observed in the presence of $2-6 \%$ oxygen in the gas phase. Catalase and oxidase are produced. No pigments are produced on King medium A or Luisetti medium. Nitrate reduction and denitrification are negative. Starch and Tween 80 are hydrolysed. The following substrates are oxidized: acetic acid, cis-aconitic acid, L-alaninamide, D-alanine, L-alanine, D-arabitol, L-asparagine, bromosuccinic acid, citric acid, formic acid, D-gluconic acid, $\alpha$-D-glucose, L-glutamic acid, glycogen, hydroxy-L-proline, $\alpha$-hydroxybutyric acid, $\beta$-hydroxybutyric acid, itaconic acid, $\alpha$-ketobutyric acid, $\alpha$-ketoglutaric acid, $\alpha$-ketovaleric acid, DL-lactic acid, L-leucine, D-mannitol, methyl pyruvate, monomethyl succinate, L-proline, propionic acid, D-psicose, L-pyroglutamic acid, D-saccharic acid, sebacic acid, succinamic acid, succinic acid and Tweens 40 and 80. The following substrates are oxidized weakly: L-alanylglycine, L-aspartic acid, D-cellobiose, D-fructose, $\gamma$-hydroxybutyric acid, $p$-hydroxyphenylacetic acid, D-serine, L-serine and $\mathrm{L}$-threonine. The $\mathrm{G}+\mathrm{C}$ content of the type strain is $66 \cdot 3 \mathrm{~mol} \%$.

The type strain, $6 \mathrm{H} 33 \mathrm{~b}^{\mathrm{T}}\left(=\mathrm{ATCC}\right.$ BAA $-1049^{\mathrm{T}}=\mathrm{JCM}$ $\left.12708^{\mathrm{T}}\right)$, was isolated from a compost pile in Japan.

\section{Acknowledgements}

We would like to thank Dr Deli Liu and Ms Maki Niiyama for contributions to the initial part of this study. This work was supported by a Grant-in-Aid of Open Competition for the Development of Innovative Technology from the Ministry of Education, Culture, Sports, Science and Technology, Japan, and a Grant-in-Aid for Exploratory Research from the Japan Society for the Promotion of Science.

\section{References}

Altschul, S. F., Madden, T. L., Schaffer, A. A., Zhang, J., Zhang, Z., Miller, W. \& Lipman, D. J. (1997). Gapped BLAST and PSI-BLAST: a new generation of protein database search programs. Nucleic Acids Res 25, 3389-3402.

Bergersen, F. J. (1991). Physiological control of nitrogenase and uptake hydrogenase. In Biology and Biochemistry of Nitrogen Fixation, pp. 76-102. Edited by M. J. Dilworth \& A. R. Glenn. Amsterdam: Elsevier.

Brosius, J., Palmer, M. L., Kennedy, P. J. \& Noller, H. F. (1978). Complete nucleotide sequence of a $16 \mathrm{~S}$ ribosomal RNA gene from Escherichia coli. Proc Natl Acad Sci U S A 75, 4801-4805.

Bürgmann, H., Widmer, F., Von Sigler, W. \& Zeyer, J. (2004). New molecular screening tools for analysis of free-living diazotrophs in soil. Appl Environ Microbiol 70, 240-247.
DeLong, E. F. (1992). Archaea in coastal marine environments. Proc Natl Acad Sci U S A 89, 5685-5689.

Desnoues, N., Lin, M., Guo, X., Ma, L., Carreño-Lopez, R. \& Elmerich, C. (2003). Nitrogen fixation genetics and regulation in a Pseudomonas stutzeri strain associated with rice. Microbiology 149, 2251-2262.

Ezaki, T., Hashimoto, Y. \& Yabuuchi, E. (1989). Fluorometric deoxyribonucleic acid-deoxyribonucleic acid hybridization in microdilution wells as an alternative to membrane filter hybridization in which radioisotopes are used to determine genetic relatedness among bacterial strains. Int J Syst Bacteriol 39, 224-229.

Felsenstein, J. (1985). Confidence limits on phylogenies: an approach using the bootstrap. Evolution 39, 783-791.

Felsenstein, J. (2002). PHYLIP (Phylogeny Inference Package), version 3.6 (alpha3). Distributed by the author. Department of Genome Sciences, University of Washington, Seattle, USA.

Hiraishi, A. (1992). Direct automated sequencing of $16 \mathrm{~S}$ rDNA amplified by polymerase chain reaction from bacterial cultures without DNA purification. Lett Appl Microbiol 15, 210-213.

Hiraishi, A., Shin, Y. K., Ueda, Y. \& Sugiyama, J. (1994). Automated sequencing of PCR-amplified $16 \mathrm{~S}$ rDNA on 'Hydrolink' gels. J Microbiol Methods 19, 145-154.

Kimura, M. (1980). A simple method for estimating evolutionary rates of base substitutions through comparative studies of nucleotide sequences. J Mol Evol 16, 111-120.

King, E. O., Ward, M. K. \& Raney, D. E. (1954). Two simple media for the demonstration of pyocyanin and fluorescein. J Lab Clin Med 44, 301-307.

Krotzky, A. \& Werner, D. (1987). Nitrogen fixation in Pseudomonas stutzeri. Arch Microbiol 147, 48-57.

Lelliott, R. A., Billing, E. \& Hayward, A. C. (1966). A determinative scheme for the fluorescent plant pathogenic pseudomonads. $J$ Appl Bacteriol 29, 470-489.

Luisetti, J., Prunier, J.-P. \& Gardan, L. (1972). Un milieu pour la mise en évidence de la production d'un pigment fluorescent par Pseudomonas mors-prunorum f. sp. persicae. Ann Phytopathol 4, 295-296 (in French).

Page, R. D. M. (1996). TREEVIEW: an application to display phylogenetic trees on personal computers. Comput Appl Biosci 12, 357-358.

Palleroni, N. J. (1984). Genus I. Pseudomonas Migula 1894. In Bergey's Manual of Systematic Bacteriology, vol. 1, pp. 141-199. Edited by N. R. Krieg \& J. G. Holt. Baltimore: Williams \& Wilkins.

Pandey, K. K., Mayilraj, S. \& Chakrabarti, T. (2002). Pseudomonas indica sp. nov., a novel butane-utilizing species. Int J Syst Evol Microbiol 52, 1559-1567.

Pearson, W. R. (2000). Flexible sequence similarity searching with the FASTA3 program package. Methods Mol Biol 132, 185-219.

Perego, M., Spiegelman, G. B. \& Hoch, J. A. (1988). Structure of the gene for the transition state regulator, $a b r B$ : regulator synthesis is controlled by the spo0A sporulation gene in Bacillus subtilis. Mol Microbiol 2, 689-699.

Saitou, N. \& Nei, M. (1987). The neighbor-joining method: a new method for reconstructing phylogenetic trees. Mol Biol Evol 4, 406-425.

Stanier, R. Y., Palleroni, N. J. \& Doudoroff, M. (1966). The aerobic pseudomonads: a taxonomic study. J Gen Microbiol 43, 159-271.

Tamaoka, J. \& Komagata, K. (1984). Determination of DNA base composition by reversed-phase high-performance liquid chromatography. FEMS Microbiol Lett 25, 125-128. 
Thompson, J. D., Gibson, T. J., Plewniak, F., Jeanmougin, F. \& Higgins, D. G. (1997). The CLUSTAL_X windows interface: flexible strategies for multiple sequence alignment aided by quality analysis tools. Nucleic Acids Res 25, 4876-4882.

Vermeiren, H., Willems, A., Schoofs, G., de Mot, R., Keijers, V., Hai, W. \& Vanderleyden, J. (1999). The rice inoculant strain Alcaligenes faecalis A15 is a nitrogen-fixing Pseudomonas stutzeri. Syst Appl Microbiol 22, 215-224.

Young, J. P. W. (1992). Phylogenetic classification of nitrogenfixing organisms. In Biological Nitrogen Fixation, pp. 43-86. Edited by G. Stacey, R. H. Burris \& H. J. Evans. New York: Chapman \& Hall. 